УДК 631.559: 633.11: 631.5.

(C) 2014

Рожкков А. О., доктор сільськогосподарських наук,

Чернобай С. В., аспірант

(науковий керівник - доктор сільськогосподарських наук А. О. Рожков)

Харківський національний аграрний університет ім. В. В. Докучаєва

\title{
УРОЖАЙНІСТЬ ЯЧМЕНЮ ЯРОГО СОРТУ ДОКУЧАСВСЬКИЙ 15 ЗАЛЕЖНО ВІД ЗАСТОСУВАННЯ РІЗНИХ НОРМ ВИСІВУ ТА ПОЗАКОРЕНЕВИХ ПІДЖИВЛЕНЬ
}

\section{Рецензент - доктор сільськогосподарських наук В. І. Філон}

У статті наведені результати досліджень, проведених упродовж 2012-2014 рр. на дослідному полі ХНАУ ім. В. В. Докучаєва, стосовно впливу застосування різних норм висіву та позакореневих підживлень посівів комплексними добривами $i$ біопрепаратами на варіабельність урожайності рослин ячменю ярого сорту Докучаєвський 15. У ході досліджень встановлено оптимальну норму висіву для досліджуваного сорту - 5,0 млн/га, яка забезпечує формування найвищої урожайності зерна. Встановлено високу ефективність комплексного застосування кристалону спеціального разом із біопрепаратом «Агро ЕМ». Порівняно з контролем, урожайність на изьому варіанті зростала з 2,31 до 2,43 m/2а. Також у ході проведеного аналізу встановлено ступінь зв'язків урожайності зерна з основними складовими структури врожаю.

Ключові слова: норма висіву, позакореневі підживлення, біопрепарати, ячмінь ярий, урожайність, комплексні добрива.

Постановка проблеми. Формування високопродуктивних агроценозів сільськогосподарських культур - складний багатоступеневий процес, у якому беруть участь чимало залежних один від одного чинників на всіх етапах органогенезу, на які по-різному впливають генетичні й екзогенні чинники.

Вивчення і комплексна оцінка окремих основних елементів технології вирощування сортів ячменю ярого на основі глибокого аналізу елементів структури формування врожаю, сортових особливостей і якості одержуваної під час цього продукції дасть можливість підвищити ефективність виробництва цієї культури [8].

У зв'язку з цим актуальним напрямом досліджень є розкриття генетичного потенціалу продуктивності рослин нових сортів, пошук оптимальних норм висіву насіння для них, а також найбільш ефективних варіантів позакореневих підживлень.
Аналіз останніх досліджень і публікацій, у яких започатковано розв'язання проблеми. Ячмінь ярий вирощують в Україні як продовольчу, кормову й технічну культуру. На сьогодні ячмінь є другою зерновою культурою в Україні. Його площі сягають 2-5 млн гектар. В Україні вирощують переважно ячмінь ярий [1]. У структурі посівних площ Лісостепу ячмінь ярий займає близько $10 \%$, а в окремі роки, коли ми змушені пересівати озимі, - 12 і навіть $15 \%$. Саме тому вивчення особливостей формування продуктивності його в системі технологічних прийомів вирощування і розробка основних елементів сортової агротехніки, адаптивності до грунтово-кліматичних умов регіону вирощування залишається актуальним. Значний вплив на формування показників продуктивності рослин мають норми висіву, від правильного застосування яких залежить ріст i розвиток рослин. Оскільки кожен регіон має певні погодні і грунтові особливості, то для кожного з них необхідно підбирати сорти, які можуть поєднувати у собі високу адаптивність до несприятливих абіотичних та біотичних чинників із достатньою потенційною продуктивністю та здатністю реалізувати iii навіть за стресових погодних умов $[2,6]$.

Нині заходи 3 вирощування ячменю ярого не забезпечують одержання бажаного врожаю внаслідок порушення технології $[4,5]$.

Оптимальна густота стояння рослин є однією з головних умов, яка визначає повноту використання природних чинників і вирощування високого врожаю належної якості. Дані попередніх досліджень i практика показують, що реакції сортів на ті чи інші агрозаходи істотно різняться. У зв'язку зі створенням нових сортів різнопланового використання, встановлення оптимальної норми висіву для них має особливе значення у ефективному використанні природних ресурсів.

У зв'язку зі швидкими і значними змінами технології вирощування ячменю, а також соці- 


\section{СІЛЬСЬКЕ ГОСПОДАРСТВО. РОСЛИННИЦТВО}

ально-економічних умов виробництва й споживання зерна, створення і впровадження у виробництво нових сортів інтенсивного, напівінтенсивного типів із різними вегетаційними періодами, потребують уточнення норми висіву, застосування позакореневих підживлень, конкретизуючи їх для кожного сорту. Протягом останнього часу районовані сорти ячменю у виробництві висівають із різними нормами висіву від: 3,0 до 6,0 млн схожого насіння на га. 3 економічної й організаційної точок зору, найбільш кардинальним шляхом $\epsilon$ впровадження у виробництво адаптованих сортів із застосуванням власних оптимальних елементів сортової технології вирощування [8].

Враховуючи специфіку грунтово-кліматичних умов та особливості нових сортів ячменю ярого, що по-різному реагують на окремі елементи технології, необхідно встановити оптимальні рівні технологічних заходів, які забезпечують отримання гарантованого врожаю. Технологія вирощування ячменю ярого повинна передбачати створення умов, за яких повністю реалізуються потенційні можливості культури за якісними та врожайними показниками. У першу чергу - це чітке дотримання агротехнічних заходів та строків їх проведення.

Мета досліджень полягала в удосконаленні технології вирощування ячменю ярого 3 метою більш повного розкриття генетичного потенціалу зернової продуктивності рослин ячменю ярого.

Завдання досліджень: визначення впливу елементів технології вирощування - норм висіву та позакореневих підживлень на врожайність зерна ячменю ярого сорту Докучаєвський 15, а також встановлення тісноти зв'язків між урожайністю й основними структурними показниками врожаю.

Методика досліджень. Дослідження проводились упродовж 2012-2014 рр. на дослідному полі Харківського НАУ ім. В. В. Докучаєва за загальноприйнятою методикою [3]. Грунт на дослідному полі - чорнозем типовий глибокий на карбонатному лесі. Вміст гумусу в орному шарі складає 4,4-4,7 \%, рухливого фосфору (за Чириковим) - 138 мг/кг, калію - 103 мг/кг грунту.

Даний двохфакторний дослід закладали методом розщеплених ділянок у трикратній повторності. У досліді визначали вплив різних норм висіву - від 4,0 до 5,5 млн/га 3 кроком градації 0,5 млн/га (чотири варіанти). Ділянками другого порядку були такі варіанти позакореневих підживлень посівів комплексними добривами та біопрепаратом «Агро ЕМ»: 1 - контроль (оброб- ка посівів водою); 2 - кристалон спеціальний; 3 - реаком; 4 - кристалон + «Агро ЕМ»; 5 - реаком + «Агро ЕМ».

Район проведення досліджень має характер нестабільного зволоження. У відношенні вологозабезпеченості кращими були погодні умови 2014 року, що позитивно вплинуло на розвиток посівів i, як наслідок, формування вищої урожайності рослин. Температурний режим періодів вегетації за роками досліджень, особливо в 2013 році, був значно вищим, у порівнянні 3 середньобагаторічними показниками.

Відмічені перевищення температурного режиму вносили значні корективи у процеси росту і розвитку рослин, формування їх зернової продуктивності. У той же час встановлені розбіжності за основними метеорологічними показниками дали змогу більш повноцінно визначити вплив досліджуваних елементів технології на ріст i розвиток посівів ячменю ярого досліджуваного copту.

Результати досліджень. У проведених дослідженнях встановлено значний вплив застосування різних норм висіву та способів сівби на варіабельність зернової продуктивності посівів ячменю ярого.

У середньому за три роки досліджень урожайність рослин ячменю ярого найбільшою була за норми висіву 5,0 млн/га - 2,49 т/га (рис.1). Порівняно з контролем, урожайність на цьому варіанті підвищувалася на 0,25 т/га (понад 11,0%) за $\mathrm{HIP}_{05}$ головного ефекту чинника А (норма висіву) $-0,1$ т/га.

За проведеним статистичним аналізом із використанням рангового критерію Уолтера-Дункана [7], за чинником А показники врожайності зерна належали до трьох гомогенних груп: 1 - контроль (2,24 т/га); 2-4,5 і 5,5 млн/га (відповідно 2,39 і 2,41 т/га); 3-5,0 млн/га (2,49 т/га).

Зміна показників урожайності зерна під час впливу позакореневих підживлень (чинник В) відбувалася в меншому діапазоні - від 2,31 до 2,43 т/га. Найбільша врожайність зерна ячменю у середньому за три роки досліджень (2,43 т/га) була на варіантах комплексного застосування кристалону з біопрепаратом «Агро ЕМ».

Оцінка досліджуваних елементів технології, як джерел варіації у мінливість результативності досліджуваної ознаки, показала більшу роль норми висіву за всіма роками досліджень. Частка цього чинника у варіабельності врожайності зерна у 2012 p., 2013 і 2014 pp. становила, відповідно, $53,1 \%, 71,4$ i $75,0 \%$ (рис. 2). 


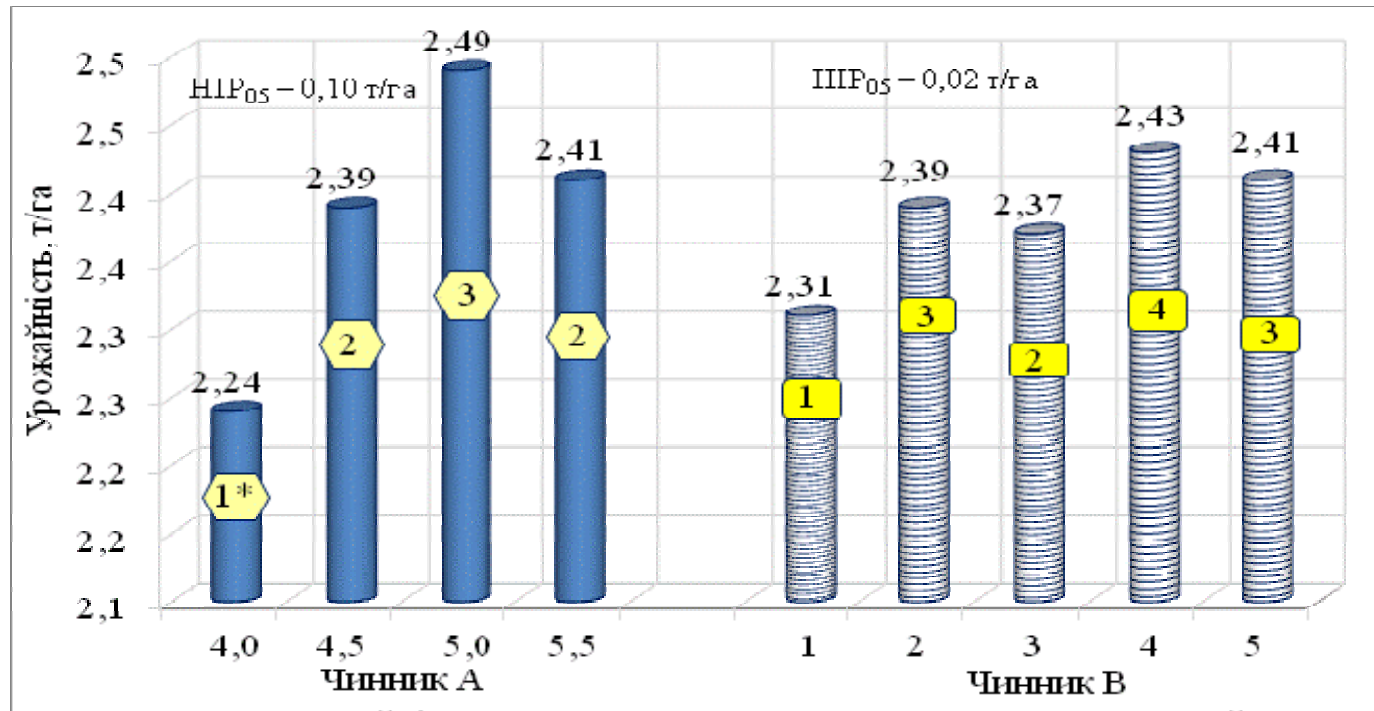

Рис. 1. Урожайність зерна ячменю ярого сорту Докучаєвськй 15 за вппиву норм висіву (чиннпк A) та позакореневих піджлппень (чиннпк В), т/га . Середнє за 2012-2011 pp. Умовні позначення: * - рангові групп: I - перша; II друга; III - третя; IV - четвер та. Варіанти піджнвпеь: 1 - контропь; 2 - крист.; 3 - реаком; 4 - крист. + агро ЕM; 5 - реаком + агро ЕМ.

1

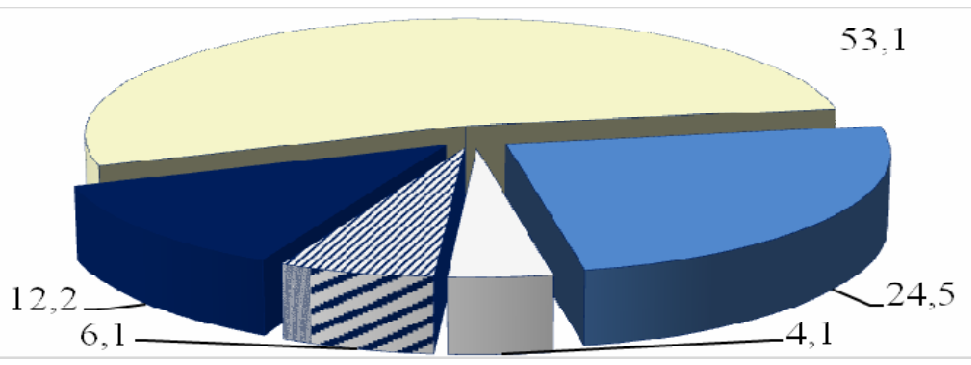

2

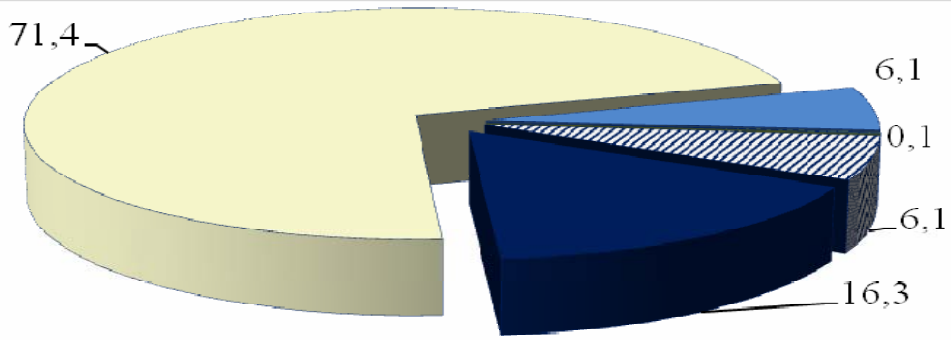

3

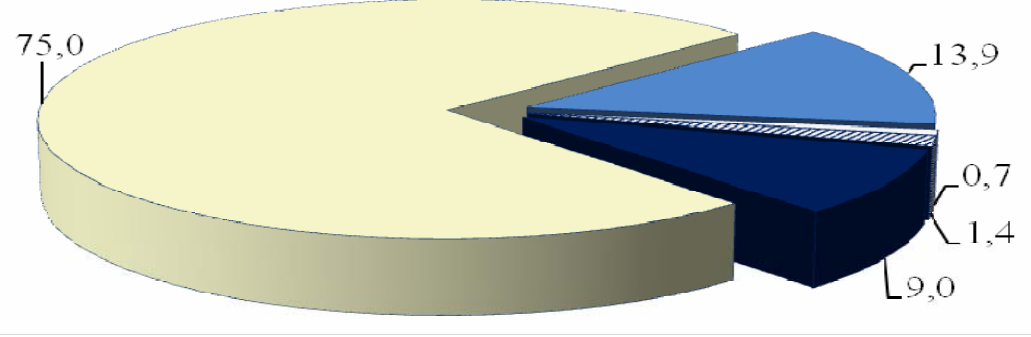

Рис. 2. Вклади досліджуваних чинників у варіабельність урожайності зерна рослин ячменю ярого за роками досліджснь, \%. Позначення $\square$ - чинник A (норма висіву); $\square$ - чинник B (позакореневі підживлення); $\square$-взаємодія А В; $\square$ - повторення; - похибки. Рік досліджень: 1 - 2012 р.; $2-2013$ p.; $3-2014$ p. 
Застосування різних варіантів позакореневих підживлень посівів рослин ячменю ярого викликало зміни врожайності у 2012 р. на 24,5 \%; 2013 р. на $6,1 \%$ і у 2014 р. - на 13,9\%. Важливо зауважити на зростаючій ролі проведення позакореневих підживлень у менш сприятливих погодних умо-

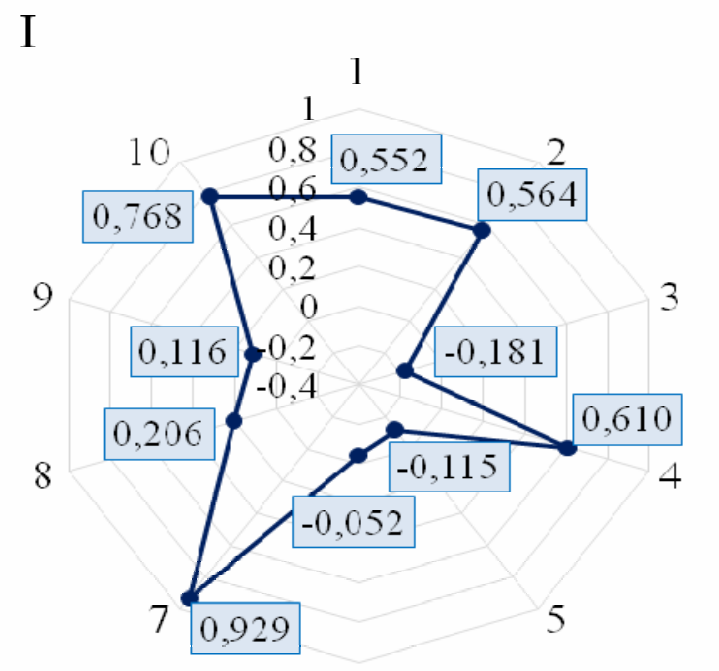

6

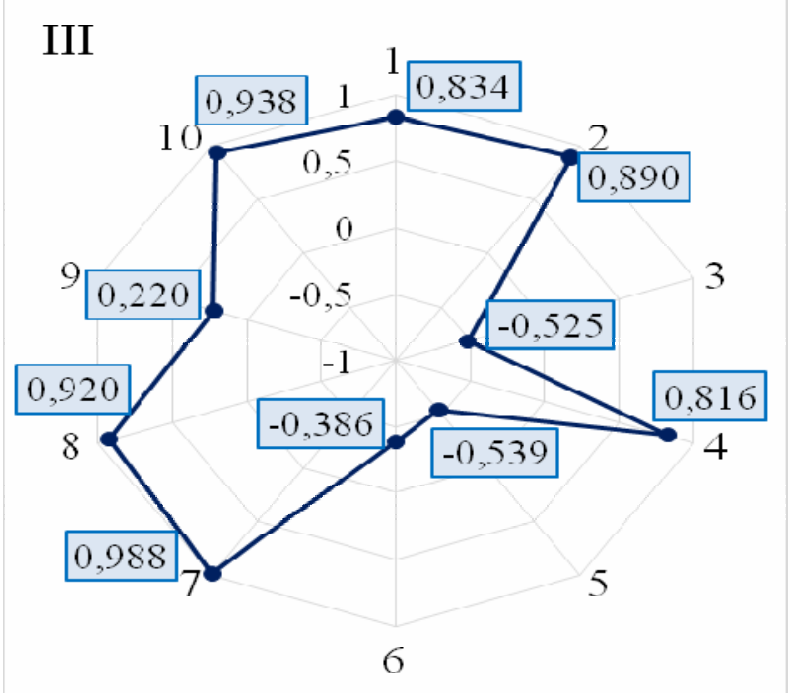

вах, як було відмічено у 2012 році.

Взаємодія досліджуваних чинників не мала істотного впливу на зміну результативності досліджуваного показника. Лише у 2010 р. статистично доведено ефект взаємодії чинників у зміні врожайності зерна ячменю ярого (4,1\%).

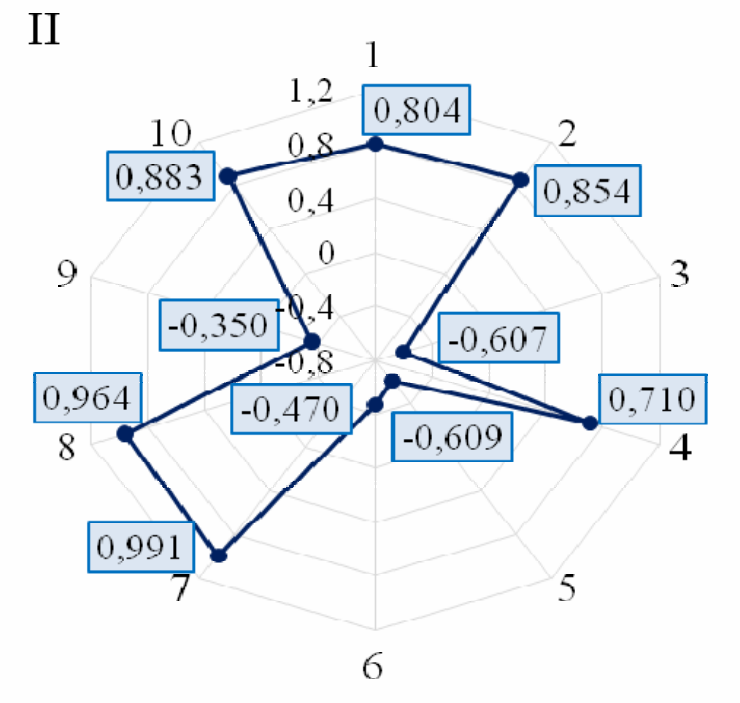

IV

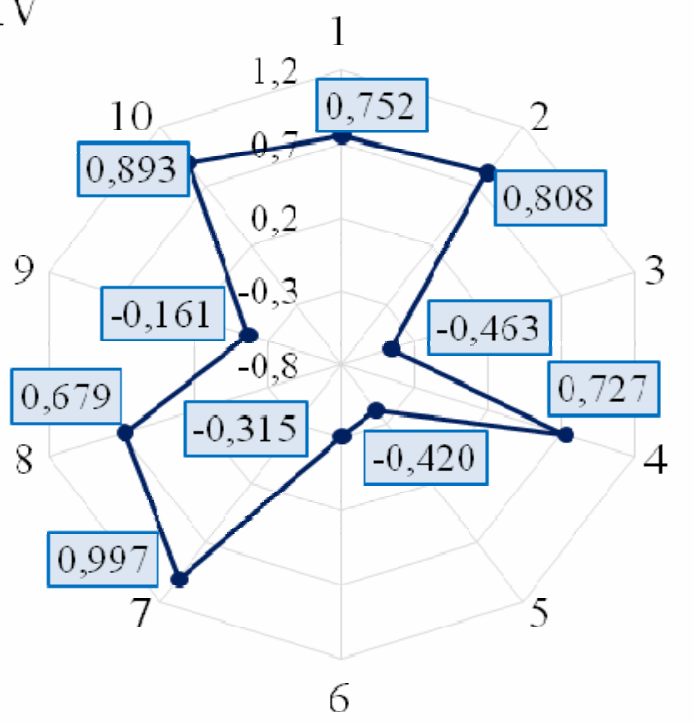

Рис. 3. Ступінь зв'язків (кореляційний зв'язок) між урожсайністю зерна рослин ячменю ярого сорту Докучаєвський 15 і ̈̈х основними біометричними показниками. Умовні скорочення: 1 - кіль-

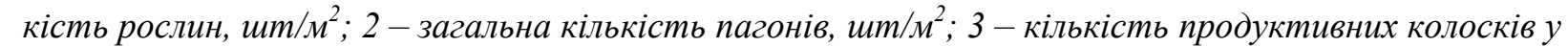
колосі, шт.; 4-довжина рослин, см; 5 -довжина колоса, см; 6-маса зерна з колоса головного

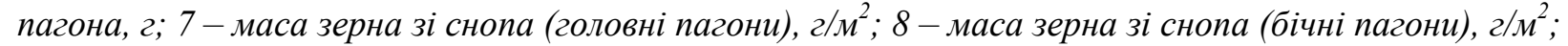
9-маса 1000 зерен, г; 10 -маса соломи зі снопа, г/м². Роки досліджень: I-2012, II-2013, III-2014, IV-середне за 2012-2014 pp. 


\section{СІЛЬСЬКЕ ГОСПОДАРСТВО. РОСЛИННИЦТВО}

Одним із завдань проведеного досліду було визначення ступеня зв'язків між зерновою продуктивністю посівів і основними складовими структури врожаю.

За роками досліджень було відзначено у цілому схожу закономірність зв'язків між досліджуваними показниками.

Зокрема, врожайність зерна в усі роки досліджень мала тісний прямий кореляційний зв'язок із кількістю рослин і пагонів на одиниці площі, довжиною рослин, масою зерна $31 \mathrm{~m}^{2}$ головних i бічних пагонів, а також із масою соломи $з$ одиниці площі посіву (рис. 3).

Зворотній зв'язок середньої сили в усі роки досліджень відзначено між урожайністю зерна й кількістю продуктивних колосків у колосі, що закономірно пояснюється тим, що під час аналізу порівнювалися пари, в тому числі й за чинником норми висіву. Цим можна також обгрунтувати зворотній зв'язок між урожайністю рослин і довжиною колоса головного пагону рослин: зі збільшенням норми висіву до певної величини врожайність у цілому зростає за рахунок більшої кількості продуктивних пагонів на одиниці площі посіву, водночас довжина колоса поступово зменшується через підвищення конкуренції у посівах.

\section{БІБЛІОГРАФІЯ}

1. Бельдій Н. Ячмінь - культура прибуткова / Н. Бельдій, М. Загинайло, А. Носуля // Пропозиція. - 2012. - С. 12-14.

2. Бомба М. Я. Формирование урожая ярового ячменя на Украине / М. Я. Бомба, М. И. Бомба [и др.] // Зерновые культуры. - 2001. - №2. C. 22-24.

3. Доспехов Б. А. Методика полевого опыта / Б. А. Доспехов. - М. : Агропромиздат, 1985. $351 \mathrm{c}$.

4. Кирюшин В. И. Состояние и перспективы освоения агротехнологий / В. И. Кирюшин, А. Л. Иванов // Нива Татарстана. - 2006. - №5-6. C. 24-27.
У середньому за роками досліджень встановлено слабкий зворотній зв'язок між урожайністю зерна та їхньою масою $1000(\mathrm{r}=-0,161)$, а також iз масою зерна 3 колоса головного пагона ( $\mathrm{r}=$ $-0,315)$. Найтіснішим $(\mathrm{r}=0,997)$ був зв'язок між урожайністю зерна й масою зерна зі снопа бічних пагонів.

Висновок. Отже, в результаті досліджень встановлена висока ефективність застосування комплексних підживлень ячменю ярого кристалоном спеціальним і біопрепаратом «Агро ЕМ». Зокрема, врожайність зерна на цьому варіанті була на 5,0 \% вищою, ніж на контролі. Ефект позакореневих підживлень зростає у стресових погодних умовах. Більш впливовим чинником на варіабельність урожайності зерна за усіма роками досліджень була норма висіву. Оптимальною нормою висіву для досліджуваного сорту ячменю ярого є 5,0 млн/га. Приріст врожайності за цієї норми порівняно 3 контролем становила понад $11,0 \%$.

Урожайність зерна має різної сили зв'язки зі структурними елементами у межах досліджуваних варіантів, серед яких більш сильним $є$ зв'язок із масою зерна головних і бічних пагонів на одиницю площі посіву.

5. Коданев И. М. Агротехнические приёмы повышения качества зерна / И. М. Коданев. Горький, 1981. - 46 с.

6. Литвиненко М. А. Зернові культури. Стан та перспективи створення нових сортів і гібридів у наукових установах УААН / М. А. Литвиненко, О. І. Рибалка // Насінництво. - 2007. - №1. C. $3-6$.

7. Литл T. Сельскохозяйственное опытное дело / Т. Литл. - М. : Колос, 1981. - 358 с.

8. Яриев Г. Ф. Нормы высева разных сортов ярового ячменя / Г. Ф. Ярцев, Р. М. Бадреев // Земледелие. - 2007. - № 5. - С. 43-44. 